\title{
Exploring the Potentials of Tailings of Bukuru Cassiterite Deposit for the Production of Iron Ore Pellets
}

\author{
O. K. Abubakre*1, Y. O. Sule ${ }^{2}$ and R. A. Muriana \\ ${ }^{1}$ Department of Mechanical Engineering \\ Federal University of Technology, Minna, Nigeria \\ ${ }^{2}$ Raw Materials Research \& Development Council, Abuja, Nigeria \\ *Corresponding Author, contact: mraremu@yahoo.com
}

\begin{abstract}
Cassiterite ore was sourced from Dogo-Na-Hawa, in Bukuru, Jos South Local Government of Plateau State, Nigeria. The ore was analyzed as mined and its various constituents noted. Previous study has shown considerable iron ore composition of the deposit. The present study entails the separation and analysis of magnetic mineral (mostly iron ore) from the ore. The beneficiated iron ore was pelletized using the facilities of the Nigerian Metallurgical Development Centre (NMDC), Jos. The pellets so produced were subjected to various tests such as drop resistance, green compressive strength, dry compressive strength at $900^{\circ} \mathrm{C}$, tumbler resistance, micro porosity and indurations compressive strength at $1100^{\circ} \mathrm{C}$. The results indicated Bukuru cassiterite contains sufficiently high grade of iron ore that could be beneficiated for iron production. The pellets produced are of good quality and could be utilized for iron and steel making.
\end{abstract}

\section{INTRODUCTION}

Cassiterite, $\mathrm{SnO}_{2}$, is the most important ore of tin. It is often found in hydrothermal veins or pegmatite, but also forms as a result of secondary processes in the oxidation zone of weathered tin deposits [1]. During erosion, cassiterite can wear down to nodules and large grains and concentrated in placer deposits. The nodules have a greasy luster and seem heavy in the hand. Some cassiterite is very black and hence tests are sometimes essentials. By reducing cassiterite to powder (white) and heating it on a block of charcoal, a globule of tin is produced. The present 
study entails the separation and analysis of magnetic mineral (mostly iron ore) from the ore. The beneficiated iron ore was pelletized using the facilities of the Nigerian Metallurgical Development Centre (NMDC), Jos. The pellets so produced were subjected to various tests such as drop resistance, green compressive strength, dry compressive strength at $900^{\circ} \mathrm{C}$, tumbler resistance, micro porosity and indurations compressive strength at $1100^{\circ} \mathrm{C}$. The results indicated Bukuru cassiterite contains sufficiently high grade of iron ore that could be beneficiated for iron production. The pellets produced are of good quality and could be utilized for iron and steel making.

\section{LITERATURE REVIEW}

\subsection{Sources of Tin Ore}

The main suppliers of tin to the ancient world were the Phoenicians who carried on a trade based on their mines and smelters in the Iberian Peninsula and on trade with Cornwall. Greek literature mentions the cassiteride, the "tin Islands" but just what these were is not clear. Cassiterites is widely distributed in small amounts but were produced on a commercial scale in only a few localities. Most of the world's supply of tin ore now comes from the Malay states, Bolivia, Indonesia, Belgian, Congo and Nigeria. Cornwall, England, has produced large amount of tin ore in the past. Tin was a rare metal in the East and had to be brought from the misty Cassiterides by sailors from Atlantic shores [2].

\subsection{Tin Mining in Nigeria}

Nigeria used to be one of the major sources of Cassiterite. Tin mining was discovered around 1700 - 1750 in Kuza near the river channel. Tin mining began to develop in local villages and trade occurred with those who came from Tripoli and crossed the Sahara. The tin would be melted and made into rolls. By 1760 - 1770, there were thirteen indigenous blacksmith smelters in Naraguta - a city located just north of Jos. The Beron ethnic group was mining and producing tin along the Delimi River for the ethnic Hausa Traders. Tin became popular during the industrial revolution in Europe. Tin was traced from Tripoli (Libya) to Bauchi (Nigeria) which served as commercial centre for tin from Jos. The Hausa traders established the buying center in Bauchi to prevent foreigners from knowing the original source of Jos tin.

In 1868, Clepparton from Britain traveled three months across the Trans Sahara to find smelters in Naraguta. As at this time, tin sources in Europe were beginning to fade [3]. By 1820, Colonel Levis from Britain was ordered to sample produce tin from Naraguta deposit. At that time, there was little knowledge among Nigerians on what tin was being used for. Awareness developed later that Spain was using the tin for gun barrels. Apart from the Naraguta deposit, many locations with viable deposit have been identified at various locations in Nigeria (Table 1). 


\subsection{Tin Processing in Nigeria}

At the dawn of the Second World War, Nigeria was already a major source of high-grade tin ore for the Tin Smelters of the Western Europe where tin was extracted for ammunition production to support the war efforts, amongst other uses. By 1960, Nigeria had established itself as an important producer of tin ore, which then became a major foreign exchange earner for the country. In 1962, Makeri Smelting Company Limited was established on the Jos Plateau by Consolidated Tin Smelters (a British company) displacing a Spanish Smelter nearby that was competing for the concentrate [4].

Table 1 Cassiterite deposits in Nigeria.

\begin{tabular}{|l|l|l|}
\hline S/N & STATES & LOCATION \\
\hline 1 & Cross River & Akaibamu, Ogoja, Obeju \\
\hline 2 & Ekiti & Ijero \\
\hline 3 & Nassarwa & Wamba \\
\hline 4 & Kaduna & Kaduna, Jama'a \\
\hline 5 & Plateau & Jos North/South \\
\hline & & Barkin - Ladi, Mangu \\
\hline & & Bassa, Panshin, Bakkos \\
\hline 6 & Kogi & Ojuwo - Olijo, Egbe, \\
\hline 7 & Adamawa & Toungu, Vere Hill \\
\hline 8 & Gombe & Kaltun \\
\hline
\end{tabular}

The science of Tin Smelting did not begin in Nigeria with the establishment of a Tin Smelter. Prior to the arrival of the European Explorer, there already existed sophisticated cultures that were vast in the art of local smelting. For many years the ore extracted by miners on the Plateau was brought by traders and taken to Lireuin (Ririwai), Delma which were important centers for the smelting process. Lireuin in Kano was the older center but by the end of the $19^{\text {th }}$ century much of the activity had been transferred to the other town when an ambitious younger brother quarreled with the head of the family and set up new furnaces at Lireuin (Ririwai) Delma with some followers. The operation of the furnaces was simple and effective. Each furnace belonged to one of the leading men of the town. Maintenance and repairs were carried out under cover of darkness to keep the art of making furnaces secret. The owners of the furnaces smelted for their town men who had enough ore to make a convenient charge of about $63.5 \mathrm{~kg}$ (140Ibs) [5].

\section{EXPERIMENTAL PROCEDURE}

\subsection{Beneficiation of the Ore}


Tin ore weighing $15.19 \mathrm{~kg}$ was collected from its Padok (field leased out by Government where mineral ore exists). The ore was dried in the sun and run on gravitational shaking machine to reduce the sand. Bucket 1 and 2 on gravitational shaking machine contains tin ore, which is then transferred to rapid double disc machine. The dried and floated tin ore $\left(\mathrm{SnO}_{2}\right)$ is now charged into the charging chamber of rapid disc machine. On this machine, which works by electromagnetic field effect, the material runs down through the conveyor belt and through the disc. At the first disc, magnetic and non magnetic minerals are separated. The magnetic mineral, iron ore, which is the most magnetic is first separated on the first disc, columbite and other less magnetic mineral are attracted by the second and third discs.

The non - magnetic mineral i.e. cassiterite or tin ore $\left(\mathrm{SnO}_{2}\right)$, monozite, zircon sand in traces, zinc and other non - magnetic ore in the mineral goes to the front (i.e. they are not being picked by any of the disc). These are known as over - belt materials. The over - belt is subjected to gravity floatation on the air float to obtain pure tin oxide. The percentage composition (by mass) of Cassiterite Ore (as mined) Samples from Padok in Dogo Na Hawa in Bukuru is presented in Table 2.

Table 2: Composition of Ore Sample from Padok

\begin{tabular}{|l|l|l|}
\hline Constituent & Composition $(\mathrm{kg})$ & Percentage Composition (\%) \\
\hline Tin & 1.98 & 13.06 \\
\hline Iron Ore & 4.83 & 31.45 \\
\hline Columbite & 0.39 & 2.5 \\
\hline $\begin{array}{l}\text { Monozite and Other non-magnetic } \\
\text { materials }\end{array}$ & 7.94 & 52.27 \\
\hline Loss during Processing & 0.062 & 0.41 \\
\hline
\end{tabular}

The analysis was carried out by Geotec Nigerian Limited, Jos.

The magnetic mineral (with iron ore as the major constituent) recovered from magnetic shaking machine was also analysed. The result of the analysis is presented in Table 3.

Table 3: ED-XRF Chemical Composition of Cassiterite Deposit from Dogo Na-Hawa in Bukuru

\begin{tabular}{|c|c|c|c|c|c|c|c|c|c|c|}
\hline Compound & $\mathrm{CaO}$ & $\mathrm{TiO}_{2}$ & $\mathrm{~V}_{2} \mathrm{O}_{5}$ & $\mathrm{Cr}_{2} \mathrm{O}_{3}$ & $\mathrm{MnO}$ & $\mathrm{Fe}_{2} \mathrm{O}_{3}$ & $\mathrm{NiO}$ & $\mathrm{CuO}$ & $\mathrm{As}_{2} \mathrm{O}_{3}$ & $\mathrm{Y}_{2} \mathrm{O}_{3}$ \\
\hline $\begin{array}{c}\text { Composition } \\
\%\end{array}$ & $\begin{array}{l}2.8 \\
\%\end{array}$ & $\begin{array}{l}16.7 \\
\%\end{array}$ & $\begin{array}{l}0.2 \\
\%\end{array}$ & $\begin{array}{l}0.93 \\
\%\end{array}$ & $\begin{array}{l}1.1 \\
\%\end{array}$ & $\begin{array}{l}23.7 \\
\%\end{array}$ & $\begin{array}{l}0.26 \\
\%\end{array}$ & $\begin{array}{l}0.50 \\
\%\end{array}$ & $\begin{array}{l}0.01 \\
\%\end{array}$ & $\begin{array}{l}0.52 \\
\%\end{array}$ \\
\hline Compound & $\mathrm{ZrO}_{2}$ & $\mathrm{Nb}_{2} \mathrm{O}_{5}$ & $\mathrm{Rh}_{2} \mathrm{O}$ & $\mathrm{SnO}_{2}$ & $\mathrm{CeO}_{2}$ & $\mathrm{Yb}_{2} \mathrm{O}_{3}$ & $\mathrm{HfO}_{2}$ & $\mathrm{PtO}_{2}$ & $\mathrm{PbO}$ & $\mathrm{ThO}_{2}$ \\
\hline $\begin{array}{c}\text { Composition } \\
\%\end{array}$ & $\begin{array}{l}29.1 \\
\%\end{array}$ & $\begin{array}{l}8.9 \\
\%\end{array}$ & $\begin{array}{l}4.0 \\
\%\end{array}$ & $\begin{array}{l}7.2 \\
\%\end{array}$ & $\begin{array}{l}0.5 \\
\%\end{array}$ & $\begin{array}{l}0.46 \\
\%\end{array}$ & $\begin{array}{l}0.81 \\
\%\end{array}$ & $\begin{array}{l}0.31 \\
\%\end{array}$ & $\begin{array}{l}0.33 \\
\%\end{array}$ & $\begin{array}{l}1.6 \\
\%\end{array}$ \\
\hline
\end{tabular}




\subsection{Characteristics of Pellets produced from the Ore}

About $3.0 \mathrm{~kg}$ of pulverized magnetic component of the ore was mixed with $0.12 \mathrm{~kg}$ of bentonite, and $450 \mathrm{ml}$ of water. Pellets of 8 to $10 \mathrm{~cm}$ were produced using palletizing disc machine. The resulting pellets were subjected to various tests to establish its suitability for use in iron production. Such test include Drop Number test, Drop Resistance, Moisture Content, Green Compressive Strength Test, Dry Compressive Strength Test at $900^{\circ} \mathrm{C}$, Tumbler resistance Test, Micro - Porosity Test, Indurating Compressive Strength Test at $1100^{\circ} \mathrm{C}$. Standard test procedure was used to determine these parameters as highlighted by Guanzhou [5] and others [6-8].

\section{RESULTS AND DISCUSSIONS}

\subsection{Chemical Composition of the Beneficiated Ore}

The chemical composition of the magnetic component of the analyzed cassiterite ore after beneficiation is shown in Table 4:

Table 4: Chemical Composition of Magnetic material (mostly Iron ore) from recovered from the cassiterite deposit

\begin{tabular}{|c|l|l|l|l|l|l|l|l|l|}
\hline Compound & $\mathrm{CaO}$ & $\mathrm{V}_{2} \mathrm{O}_{5}$ & $\mathrm{MnO}$ & $\mathrm{Fe}_{2} \mathrm{O}_{3}$ & $\mathrm{ZrO}_{2}$ & $\mathrm{Nb}_{2} \mathrm{O}_{5}$ & $\mathrm{Rh}_{2} \mathrm{O}_{3}$ & $\mathrm{TiO}_{2}$ & Others \\
\hline Composition & 0.89 & 0.83 & 1.10 & 42.40 & 0.63 & 0.86 & 2.00 & 34.50 & 16.69 \\
$\%$ & $\%$ & $\%$ & $\%$ & $\%$ & $\%$ & $\%$ & $\%$ & $\%$ & $\%$ \\
\hline
\end{tabular}

There is a noticeable increase in the iron ore content of the primary ore by 44 percent.

\subsection{Drop Number and Drop Resistance Test}

The result obtained form Drop Number test and Drop Resistance test are presented in Table 5.

Table 5 Result of Drop Number and Drop Resistance Tests

\begin{tabular}{|l|l|l|l|l|l|l|l|l|}
\hline S/N & 1 & 2 & 3 & 4 & 5 & 6 & 7 & 8 \\
\hline Height $(\mathrm{cm})$ & 60 & 46 & 46 & 46 & 60 & 46 & 60 & 60 \\
\hline Drop nos & 3 & 4 & 4 & 4 & 3 & 4 & 3 & 2 \\
\hline Drop Height $(\mathrm{cm})$ & 72 & 60 & 48 & 36 & 48 & 72 & 36 & 60 \\
\hline Drop Resistance nos & 2 & 2 & 2 & 4 & 2 & 2 & 3 & 3 \\
\hline
\end{tabular}

The Drop number test can be carried out at the height of $46 \mathrm{~cm}$ to $60 \mathrm{~cm}$. When carried out at the height of $46 \mathrm{~cm}$, the average drop number is 4 . The result of the test carried out from the height of $60 \mathrm{~cm}$ for eight green pellets has an average drop number of 3. Similarly, Drop 
Resistance number ranging between 2 and 3 was obtained for the various heights of $36 \mathrm{~cm}$ to 72 $\mathrm{cm}$. These values are an indication of the admissible height difference at various transfer points during green ball transformation.

\subsection{Moisture Content of the Iron ore}

The moisture content of the pulverized iron ore was determined. The weight of pulverized iron ore stabilized after sun drying and firing for 30 minutes at $200^{\circ} \mathrm{C}$. An average weight loss of 0.6 grams was observed which represents $0.6 \%$ moisture content.

\subsection{Compressive Strength}

It is apparent from practical operation that pellet consumers demand a minimum strength of an average sample of about 2,000 N/pellet. 8 pellets were used for the test and the strength for the untreated pellets is presented in Table 8. The average compressive strength at $900^{\circ} \mathrm{C}$ is $3.37 \mathrm{kN} /$ pellet. Similar test was carried out for pellets subjected to Heat treatment and the result is presented in the second column of Table 8 . The average strength of the treated pellets is 3.83 $\mathrm{kN} /$ Pellet

Table 6: Results Dry Compressive Strength of Treated and Non-Treated Ore

\begin{tabular}{|l|cc|c|}
\hline PELLETS & $\begin{array}{l}\text { Compressive } \\
(\mathrm{kN} / \text { PELLET })\end{array}$ & Strength & $\begin{array}{l}\text { Compressive Strength after Heat } \\
\text { Treatment (kN/PELLET) }\end{array}$ \\
\hline 1 & 3.24 & 3.78 \\
2 & 3.62 & 3.88 \\
3 & 4.16 & 3.49 \\
4 & 3.22 & 3.91 \\
5 & 3.54 & 3.94 \\
6 & 3.50 & 3.94 \\
7 & 2.60 & 3.70 \\
8 & 3.09 & 3.98 \\
AVERAGE & 3.37 & 3.83 \\
\hline
\end{tabular}

This shows some relative hardening of the pellets subjected to heat treatment process.

\subsection{Tumbler Test}

The tumbler test was carried out and the results obtained are as presented in Table 7 
Table 7: Result of Tumbler Test

\begin{tabular}{|l|l|l|l|l|l|l|}
\hline $\begin{array}{l}\text { Weight } \\
\text { of } \\
\begin{array}{l}\text { Sample } \\
(B)\end{array}\end{array}$ & $\begin{array}{l}\text { Abrassive } \\
\text { weight } \\
(\mathrm{A})\end{array}$ & $\begin{array}{l}\text { Tumbler } \\
\text { weight } \\
(\mathrm{C})\end{array}$ & $\begin{array}{l}\text { Abbrassive } \\
\text { index } \\
\{(\mathrm{A} / \mathrm{B}) \times 100\}\end{array}$ & $\begin{array}{l}\text { Tumbler } \\
\text { index } \\
\{(\mathrm{C} / \mathrm{B}) \times 100\}\end{array}$ & $\begin{array}{l}\text { Losses in } \\
\text { Abbrassion } \\
(\mathrm{D})\end{array}$ & $\begin{array}{l}\% \text { losses } \\
\{(\mathrm{D} / \mathrm{B}) \times 100\}\end{array}$ \\
\hline $127.35 \mathrm{~g}$ & $71.9 \mathrm{~g}$ & $53.6 \mathrm{~g}$ & $56.46 \%$ & $42.09 \%$ & $1.85 \mathrm{~g}$ & $1.45 \%$ \\
\hline
\end{tabular}

\subsection{Green Compressive Strength Test at $100^{\circ} \mathrm{C}$}

The average compressive strength obtained after subjecting six different pellets to compressive strength test is $0.23 \mathrm{kN} /$ Pellet. In a very few cases it could be possible to use green balls directly in metallurgical processes despite their low mechanical strength. Pellets must have a substantially higher strength primarily to withstand their transportation and the stresses occurring in metallurgical operations.

This test method is carried out to provide a relative measure of the resistance of iron ore pellets to degradation by impact and abrasion.

\subsection{Micro - Porosity Test}

The micro porosity test was conducted and the result is as presented in the Table 8 below:

Table 8: Micro porosity of Pellets

\begin{tabular}{|c|c|c|c|c|c|c|}
\hline & \multicolumn{2}{|c|}{ Weight (g) } & \multirow{2}{*}{$\begin{array}{l}\text { Volume } \\
\left(\mathrm{cm}^{3}\right)\end{array}$} & \multicolumn{2}{|l|}{ Density $\left(\mathrm{g} / \mathrm{cm}^{3}\right)$} & \multirow{2}{*}{$\begin{array}{l}\text { Porosity } \\
\left(P=1-\rho_{\mathrm{a}} / \rho_{\mathrm{t}}\right) \mathrm{X} \\
100(\%)\end{array}$} \\
\hline & Initial & Final & & $\begin{array}{l}\text { Apparent } \\
\left.\rho_{\mathrm{a}}\right)\end{array}$ & $\begin{array}{l}\text { True }(\rho \\
t)\end{array}$ & \\
\hline First Pellet & 37.70 & 39.60 & 8.18 & 4.61 & 4.85 & 5.86 \\
\hline Second Pellet & 36.80 & 39.10 & 8.18 & 4.50 & 4.78 & 4.95 \\
\hline
\end{tabular}

The porosity is measured on the dry balls. Total porosity of a pellet is expressed as the ratio of pore volume to total volume of the pellet and is calculated using the difference between the true density and apparent density. Porosity of a pellet is an important property to ascertain pellet quality. Porosity affects the compressive strength, thermal conductivity. It also plays important role in controlling its swelling during its reduction. Kasai and Murayama [9] reported an increase in thermal conductivity with decrease in porosity for coke pellets.

\subsection{Indurating Compressive Strength Test at $1100^{\circ} \mathrm{C}$}


The indurations impart such characteristics to the pellets as are imperative both for their transportation and metallurgical treatment. It is the last processing step to impart substantially higher strength. The produced pellet with an average compressive strength of $5.2 \mathrm{kN} /$ Pellet more than satisfies the minimum strength requirement of $2 \mathrm{kN} /$ Pellet. The strength of pellet can further be increased by increasing the percentage of binder.

\section{CONCLUSION}

Cassiterite was sourced from Dogo Na Hawa in Bukuru, Jos South Local Government Area of Plateau State. The ore was analyzed and the various constituents of the ore ascertained. The iron ore content of the ore as mined was $31.45 \%$. After magnetic separation of the iron ore from the cassiterite ore, it was then analyzed and was found to be $42.40 \%$.

The iron ore was pelletized using the equipment available at the National Metallurgical development Centre (NMDC), Jos and the results were compared with properties of pellets required for use for DRI process of iron and steel making and Blast furnace process. The pelletised iron ore were found to be suitable for any of the two processes.

Though iron ore from cassiterite is good enough for iron and steel production, abundant availability of iron ore in the earth crust and in Nigeria in particular does not make cassiterite a viable source of iron ore for iron and steel production today and in the near future.

\section{REFERENCES}

[1] Adams, H., 2001, Columbia Encyclopedia, Sixth Edition, available at www.bartleby.com

[2] Calvert, J.B., 2000, Tin 4, available at www.du.edu/ jcalvert/phys/tin.htm

[3] Natasha, C., 2002, Tin mining of the Jos plateau, available at www.uni.edu/gai/nigeria/lessons/tin-mining.htm

[4] Gibson, O., 2002, "Tin Smelting in Nigeria - the Challenge of our time." Proceedings of the $19^{\text {th }}$ Annual Conference/AGM of the Nigerian Metallurgical Society, pp. $47-60$.

[5] Guanzhou, Q., Tao, J., Zhucheng H., Deqing, Z., and Xiaohui, F., 2002, "Characterization of Preparing Cold Bonded pellets for Direct Reduction using an Organic Binder." ISIJ International Journal, Vol. 4, pp. 20 - 25.

[6] Kurt, M., 1980, Pelletizing of Iron Ore, Springer - Verlag Berlin Heidelberg, New York.

[7] Rumpf, H., 1962, "The Strength of Granules and Agglomerates." Agglomeration (ed. W.A. Knepper), New York.

[8] Tohidi, N., and Rames, V., 1997, "Preparation of Iron and Steel Burden." Seminar paper presented at Tehran University.

[9] Kasai A., Murayama T., and Ono Y., 1993, "Measurement of Effective Thermal Conductivity of Coke.” ISIJ International, Vol. 33, pp. 697 - 702. 